WOJCIECH JAKÓBIK

Instytut Jagielloński

\title{
Koncepcja prometeizmu energetycznego? Konsekwencje rosyjsko-ukraińskiego kryzysu gazowego w 2018 r.
}

\author{
The Concept of Energy Prometheism? \\ The Consequences of the Russian-Ukrainian Gas Crisis in 2018
}

The article describes a dispute over contracts for supplies and transmission of natural gas through Ukraine from March 2018. The concept of energy Prometheism in relation to bilateral relations between Russia and Ukraine and the historical context of the crisis are also presented. The author analyses the consequences of the crisis for Ukraine and predicts further development of the situation. He also assesses the impact of the European Union's involvement in the dispute.

Keywords: energy policy, energy Prometheism, natural gas, Ukraine, Russia, Gazprom.

W marcu 2018 r. doszło do sporu o warunki dostaw i przesyłu gazu przez Ukrainę między ukraińskim Naftogazem a rosyjskim Gazpromem. Celem tekstu jest próba analizy koncepcji prometeizmu energetycznego, czyli wykorzystania myśli prometejskiej do wzmocnienia współpracy między Unią Europejską a Ukrainą. Impulsem do bliższej kooperacji ukraińsko-unijnej są kolejne kryzysy energetyczne w relacjach Rosja-Ukraina.

\section{Koncepcja prometeizmu energetycznego a kryzysy gazowe w relacjach Rosji i Ukrainy}

Historia ukraińskiej zależności gazowej od Rosji dostarcza wielu przykładów nadużyć po stronie rosyjskiej. Dyskusja na ten temat toczy się na płaszczyźnie eksperckiej i naukowej ${ }^{1}$. Na temat kolejnych kryzysów gazowych piszą

1 Por.: E. Wyciszkiewicz (red.), Geopolityka rurociagów. Wspólzależność energetyczna a stosunki międzypaństwowe na obszarze postsowieckim, Polski Instytut Spraw Międzynarodowych, Warszawa 2008; K.M. Pronińska, Bezpieczeństwo energetyczne w stosunkach UE-Rosja, Dom Wydawniczy Elipsa, Warszawa 2012; A. Zawisza, Gaz dla Polski. Zarys historii sektora gazu ziemnego w ostatnich dwóch dekadach $w$ Polsce, Instytut 
m.in. polskie ośrodki analityczne ${ }^{2,3}$. Nowym przyczynkiem do dyskusji może być koncepcja prometeizmu energetycznego. Historycznie prometeizm był romantycznym ruchem ideowym, który narodził się w XIX w. Zakładał, że wolne narody powinny nieść wolność narodom zniewolonym i robić to bezinteresownie. W polskiej polityce zagranicznej II RP ten pomysł został przekształcony przez ruch prometejski w postulat zwalczania imperializmu rosyjskiego przez wspieranie ruchów niepodległościowych na terytorium Związku Sowieckiego ${ }^{4}$. W III RP przekształcił się zaś w ruch na rzecz integracji europejskiej w ramach Unii Europejskiej (UE) i Organizacji Paktu Północnoatlantyckiego (NATO). $\mathrm{W}$ polityce energetycznej można zamienić prometeizm w postulat promowania przez Polskę, znajdującą się już w ramach regulacji europejskich, dających wolność na rynku energii i gazu, trzeciego pakietu energetycznego, liberalizującego obrót tymi dobrami w krajach uzależnionych od surowców energetycznych z Rosji. Jest to postulat dotyczący wykorzystywania zewnętrznej polityki energetyczno-klimatycznej UE w polskiej polityce wschodniej do obrony przed nadużyciami wynikającymi z podporządkowania polityki rosyjskiego Gazpromu priorytetom polityki zagranicznej Federacji Rosyjskiej ${ }^{5}$.

W literaturze przedmiotu podkreśla się, że „Gazprom jest firmą traktowaną jako monopol państwowy, którego istnienie jest uzależnione od wzajemnie świadczonych sobie usług przez organa państwowe i firmę [...] ujmowany jest w koncepcji rosyjskiej jako element budowania rosyjskiego bezpieczeństwa energetycznego. Przejawia się to w kreowaniu kryzysów energetycznych, a przez to uzyskiwaniu politycznego wpływu na kontynencie"6. W przypadku Ukrainy zasadniczym narzędziem nacisku jest polityka cenowa, a także podwa-

Sobieskiego, Warszawa 2011; M. Zygar, W. Paniuszkin, Gazprom. Rosyjska broń, przeł. K. Romanowska, W.A.B., Warszawa 2008.

2 S. Kardaś, W. Konończuk, A. Łoskot-Strachota, Negocjacje gazowe Ukraina-Rosja-UE: wojna pozycyjna, Ośrodek Studiów Wschodnich, 8.10.2017, www.osw.waw.pl/pl/ publikacje/analizy/2014-10-08/negocjacje-gazowe-ukraina-rosja-ue-wojna-pozycyjna (dostęp: 24.03.2018).

3 B. Bieliszczuk, A. Gawlikowska-Fyk, Komentarz PISM: Konflikt gazowy Rosja-Ukraina - kolejna odstona, 5.03.2018, www.pism.pl/publikacje/komentarz/nr-13-2018 (dostęp: 24.03.2018).

4 Por. P. Libera, II Rzeczpospolita wobec ruchu prometejskiego, Centralne Archiwum Wojskowe im. mjr. Bolesława Waligóry, Warszawa-Tetragon 2013, s. 15-18; W. Bączkowski, Czy prometeizm jest fikcja i fantazją?, w: W. Bączkowski, O wschodnich problemach Polski, oprac. J. Kloczkowski, P. Kowal, Ośrodek Myśli Politycznej, Księgarnia Akademicka, Kraków 2000.

5 W. Jakóbik, Prometeizm energetyczny. Między kawiarniq a politechnika, „Pressje” 2013, teka 32/33, s. 298-307.

6 L. Michalczyk, Polska a Gazprom w dtugofalowej koncepcji polskiego bezpieczeństwa energetycznego, „Polityka Energetyczna” 2011, t. 14, z. 1, s. 101. 
żenie reputacji tego kraju jako państwa tranzytowego w celu promocji nowego projektu gazociągu Nord Stream $2^{7}$. Ten z kolei ma uniezależnić Rosję od szlaku ukraińskiego i wystawić dotychczasowego pośrednika na groźbę agresywnej polityki cenowej bez negatywnych konsekwencji dla odbiorców w Unii Europejskiej, której kraje w przeszłości ograniczały już działanie Gazpromu na Ukrainie. Brak zagrożenia dla dostaw do Europy dzięki Nord Stream 2 mógłby sprawić, że zainteresowanie UE kryzysami gazowymi zmaleje.

Okazuje się, że odpowiedzią na tę politykę może być eksport regulacji unijnych chroniących przed monopolami przez realizację polityki energetycznej UE wobec państw Partnerstwa Wschodniego. Głównym narzędziem tej polityki pozostaje Wspólnota Energetyczna, za której pośrednictwem państwa stowarzyszone przyjmują unijne regulacje dla sektora energii elektrycznej i gazu ${ }^{8}$. Integracja europejska Ukrainy za pośrednictwem Wspólnoty Energetycznej sprawia, że w skomplikowane relacje rosyjsko-ukraińskie w sektorze gazowym mogą włączyć się instytucje europejskie. Warto zbadać, czy ich ingerencja umożliwi, jeśli nie zniweluje, ograniczenie wpływu polityki zagranicznej Kremla za pośrednictwem Gazpromu na stabilność państwa ukraińskiego. Autor artykułu postara się udowodnić, że dzięki temu Polska może realizować cel zmniejszenia wpływów rosyjskiego Gazpromu, a także polityki zagranicznej Federacji Rosyjskiej na region Europy Środkowo-Wschodniej na przykładzie Ukrainy, na czele z ostatnim kryzysem gazowym z marca 2018 r.

\section{Historyczny kontekst kryzysu}

Problemy Ukrainy z rosyjskim dostawcą gazu mają długą historię. Opisało je szczegółowo wielu autorów reprezentujących Ośrodek Studiów Wschodnich (OSW). Jego eksperci dzielą historię sporów gazowych Ukraina-Rosja na trzy okresy $^{9}$. Pierwszy to lata 1991-2004, kiedy Gazprom miał bezdyskusyjnie dominującą pozycję na rynku ukraińskim. Przez pierwsze 15 lat dostawy były tanie i subsydiowane, zaniżane kosztem rosyjskiego budżetu. Szymon Kardaś i Tomasz Iwański z OSW wskazują, że na handlu rosyjskim gazem bogaciła się

7 B. Bieliszczuk, A. Gawlikowska-Fyk, Komentarz PISM: Konflikt gazowy Rosja-Ukraina...

8 P. Kowal, W. Jakóbik, Polityka energetyczna UE wobec państw Partnerstwa Wschodniego (2008-2014), w: M. Grela, Z. Rapacki (red.), Partnerstwo Wschodnie Unii Europejskiej, Akademia Finansów i Biznesu Vistula, Warszawa 2016.

9 S. Kardaś, T. Iwański, Od wasalizacji do emancypacji. Rewizja modelu ukraińsko-rosyjskiej wspótpracy gazowej, Ośrodek Studiów Wschodnich, 7.03.2018, www.osw. waw.pl/pl/publikacje/komentarze-osw/2018-03-07/od-wasalizacji-do-emancypacjirewizja-modelu-ukrainsko (dostęp 1.03.2018). 
ukraińska oligarchia. Mimo to ukraiński Naftogaz powoli zmniejszał import gazu z Rosji z 70 do $50 \mathrm{mld} \mathrm{m}^{3}$ rocznie. Relacje ulegały każdorazowo pogorszeniu, gdy polityka zagraniczna Ukrainy była niezgodna $\mathrm{z}$ interesem Rosjan. Drugi okres zaczyna się wraz z pomarańczową rewolucją na Ukrainie w 2005 r., której jedną z konsekwencji był kryzys gazowy z 2006 r. Skutkiem tego było wprowadzenie pośrednika RosUkrEnergo, który według ustaleń OSW promował interesy rosyjskie w życiu publicznym Ukrainy. Rok 2009 zaczął się kolejną wojną gazową, która zakończyła się podpisaniem niekorzystnej umowy tranzytowej do 2019 r. Trzeci okres rozpoczął się po sformowaniu rządu Arsenija Jaceniuka po rewolucji Euromajdanu z 2014 r. Wtedy to Ukraina zrezygnowała z dostaw gazu z Rosji, którego nie sprowadza od listopada 2015 r. W okresie będącym przedmiotem tej analizy Rosja także zmieniała swoje podejście do relacji gazowych z Ukrainą. W pierwszych dwóch dekadach po upadku Związku Sowieckiego ukraińskie gazociągi stanowiły główny szlak dostaw gazu z Rosji do Europy. Jednak Rosjanie postanowili uniezależnić się, budując z pomocą zachodnich spółek gazociąg Nord Stream 1 (2012 r.) i proponując budowę gazociągu Nord Stream 2 (2015 r.). Jedną z konsekwencji tych działań po stronie europejskiej było przyjęcie jednego z elementów pakietu regulacji chroniących przed monopolistami, jak Gazprom, czyli trzeciego pakietu energetycznego. Ukraina także została przyjęta do Wspólnoty Energetycznej. W zamian za przeprowadzenie reform miała otrzymać wsparcie, dzięki któremu mogłaby zmodernizować gazociągi i zmniejszenie swą zależność gazową od Rosji.

Ważnym elementem nacisku politycznego Rosji w celu odwrócenia kursu rządu ukraińskiego w kierunku integracji europejskiej były w 2013 r. negocjacje gazowe. Okazało się, że dotąd subsydiowane przez Gazprom ceny gazu są ,nierynkowe" $i$ jednego dnia wzrosły z około 250 do ponad 400 dolarów za $1000 \mathrm{~m}^{310}$. Dopiero rezygnacja z podpisania umowy stowarzyszeniowej z Unią Europejską przez prezydenta Wiktora Janukowycza na szczycie Partnerstwa Wschodniego w Wilnie w 2013 r. spowodowała, że podpisano układ o utrzymaniu niższej ceny oraz pożyczkach z Rosji. Jednak w odpowiedzi na działania Janukowycza na Ukrainie doszło do wybuchu protestów społecznych zwanych rewolucją godności ze wszystkimi tego implikacjami politycznymi. OSW przewiduje kolejny etap relacji gazowych z Rosją, czyli emancypacji Ukrainy ${ }^{11}$. Państwo ukraińskie podjęło wysiłki na rzecz przyspieszenia reform, jakich wymaga od nie-

10 Ukraine had to buy gas in Europe at ransom price, EADaily, 5.03.2018, https://eadaily.com/en/news/2018/03/05/ukraine-had-to-buy-gas-in-europe-at-ransom-price (dostęp: 22.05.2018).

11 Ibidem. 
go Wspólnota Energetyczna, ale były one opóźniane przez oligarchów, mających niejasne powiązania biznesowe z Rosją. Zaczęli oni zmniejszać zużycie gazu i jego import, od listopada 2015 r. przestali importować go od Gazpromu. W relacje z Rosją aktywnie włączyła się Komisja Europejska, której mediacje w latach 2014-2015 pozwoliły uniknąć nowych konfliktów gazowych. Oznacza to, że integracja energetyczna Ukrainy z Unią Europejską utrudnia działania przeciwko niej. Dalsza integracja może zaś doprowadzić do zmniejszenia wpływu Gazpromu na politykę Ukrainy, a co za tym idzie, jego znaczenia dla polityki zagranicznej Federacji Rosyjskiej wobec tego kraju.

Po zmianach politycznych na Ukrainie w 2014 r. i nielegalnej aneksji Krymu przez Federację Rosyjską, a także rozpoczęciu przez nią działań zbrojnych we wschodniej części terytorium ukraińskiego władze w Kijowie za jeden z kluczowych postulatów polityki zagranicznej uznały uniezależnienie się od dostaw gazu ziemnego z Rosji. Dzięki ograniczeniu zużycia gazu, zwiększeniu krajowego wydobycia i wsparciu finansowemu Komisji Europejskiej, USA oraz Międzynarodowego Funduszu Walutowego na rzecz uruchomienia importu z Unii Europejskiej, Ukraina zdołała zrezygnować z importu gazu ziemnego z Rosji w listopadzie 2015 r.

Ponieważ nowe władze w Kijowie dążyły do rewizji polityki energetycznej kraju i podchodziły krytycznie do dotychczasowych relacji z rosyjskim Gazpromem, przedstawiciele ukraińskiego Naftogazu zakwestionowali w sądzie umowy na dostawy i przesył gazu z Rosji. W 2014 r. rozpoczęło się postępowanie arbitrażowe w sprawie tych kontraktów. Pierwszy z nich z 2009 r. dotyczy dostaw gazu ziemnego. Przedmiotem sporu trwającego od 2014 r. jest klauzula take or pay obligująca Ukrainę do zapłaty za około $80 \%$ dostaw wynoszących $52 \mathrm{mld} \mathrm{m}^{3}$ rocznie niezależnie od faktycznego zapotrzebowania, a także cena gazu. Drugi kontrakt dotyczy przesyłu gazu przez terytorium ukraińskie i zawiera klauzulę ship or pay, która zmusza dostawcę do świadczenia minimalnego poziomu tranzytu przewidzianego w umowie, oraz wysokość taryf tranzytowych. W analizie Polskiego Instytutu Spraw Międzynarodowych można znaleźć podsumowanie roszczeń: „Naftogaz domaga się od Gazpromu 18 mld dol. rekompensaty za zawyżone płatności za dostawy gazu oraz 12,3 mld dol. za zaniżony tranzyt i opłaty za tę usługę. Z kolei Gazprom żąda 47,1 mld dol. za niewypełnianie klauzuli take or pay i zaniżone ceny gazu dostarczonego na przełomie lat 2013/2014 oraz $7 \mathrm{mln}$ dol. związanych z tranzytem" ${ }^{\prime 2}$.

12 B. Bieliszczuk, A. Gawlikowska-Fyk, Komentarz PISM: Werdykt Trybunatu Arbitrażowego w sporze Gazprom-Naftogaz, 11.06.2017, www.pism.pl/publikacje/komentarz/nr18-2017 (dostęp: 11.06.2018). 
W sumie wzajemne roszczenia sięgały 125 mld USD. Oba kontrakty obowiązują do końca 2019 r. Ostateczna decyzja została ogłoszona 22 grudnia 2017 r. w sprawie umowy na dostawy i 28 lutego 2018 r. w sprawie kontraktu przesyłowego.

Trybunał Arbitrażowy w Sztokholmie orzekł 22 grudnia 2017 r, że Gazprom musi zrewidować umowę na dostawy gazu dla Naftogazu. Zobowiązanie do zakupu minimalnego wolumenu zostało obniżone ponad dziesięciokrotnie. Cena gazu w drugim kwartale 2014 r. została obniżona o $27 \%$ z 485 do 352 USD za $1000 \mathrm{~m}^{3}$, co dało oszczędności 1,8 mld USD na zakupach w latach 2014-2015. Sąd odrzucił roszczenia Gazpromu z tytułu niewypełnienia klauzuli take or pay sięgające 56 mld USD $^{13}$. Ponadto podważył klauzulę kontraktu o zakazie reeksportu surowca, przyznał Naftogazowi prawo do rewizji formuły cenowej w celu dostosowania jej do warunków rynkowych. W przyszłości mają zostać rozstrzygnięte pozostałe roszczenia stron ${ }^{14}$.

Wyrok sądu arbitrażowego w sprawie umowy tranzytowej zapadł na korzyść ukraińskiego Naftogazu. Narzucono Gazpromowi karę sięgającą 3,1 mld USD, ale jednocześnie wymuszono na stronie ukraińskiej zakup minimum $4 \mathrm{mld} \mathrm{m}^{3}$ rosyjskiego gazu rocznie i spłatę około 2 mld USD długu ${ }^{15}$. W sporze Naftogaz zgłosił roszczenia dotyczące niedostarczonego gazu i niedopłaty za tranzyt w wysokości 15 mld USD, a Gazprom przedstawił swoje - na 0,05 mld USD na podstawie ceny obniżonej w arbitrażu dotyczącym kontraktu na dostawy gazu, który został zakończony w grudniu 2017 r. Zobowiązanie Naftogazu do zakupu gazu z Rosji zmniejszono z 41,6 do $4 \mathrm{mld} \mathrm{m}^{3}$ rocznie, co pozwoliło zaoszczędzić ukraińskiej spółce 21,2 mld USD. Trybunał obniżył także retroaktywnie ceny dostaw w latach 2014 i 2015 o 1,8 mld USD. Rewizja ta miała według Naftogazu obniżyć koszty dostaw w 2018 i 2019 r. o ponad 0,5 mld USD. Połączona wartość roszczeń w arbitrażu dotyczącym kontraktu na dostawy gazu uczyniła go największym w historii tego typu sporem ${ }^{16}$.

13 Naftogaz wins the gas sales arbitration case against Gazprom on all issues in dispute, Naftogaz, 22.12.2017, www.naftogaz.com/www/3/nakweben.nsf/0/1CBBBA42E2336F DCC22581FE0042E27F?OpenDocument\&year=2017\&month=12\&nt=News\& (dostęp: 18.03.2018).

14 B. Bieliszczuk, A. Gawlikowska-Fyk, Komentarz PISM: Werdykt Trybunatu Arbitrażowego w sporze...

15 B. Bieliszczuk, Komentarz PISM: Rozstrzygnięcie w sprawie Naftogaz-Gazprom: porażka Rosji, szansa dla Ukrainy, 1.03.2018, www.pism.pl/publikacje/komentarz/nr-11-2018 (dostęp: 22.05.2018).

16 Win for Naftogaz in the Gas Transit Arbitration with Gazprom. Gazprom to pay USD 2.56 billion to Naftogaz, Naftogaz, 28.02.2018, www.naftogaz.com/www/3/nakweben. nsf/0/4927C1CECCAC4969C22582420076095F?OpenDocument\&year=2018\&month=02\&nt=News\&, (dostęp: 18.03.2018). 
Przed ogłoszeniem wyroku Rosjanie zobowiązali się, że mu się podporządkują, co wynika z zasad postępowania arbitrażowego, które - o czym można przekonać się w dalszej części tekstu - mogą zostać złamane. Według rządu ukraińskiego Gazprom zaproponował aneks do umowy na dostawy, w którym miało być opisane, w jaki sposób wdrożyć orzeczenie arbitrażu. Ostatecznie nie podpisano go ${ }^{17}$. Jeszcze w dniu ogłoszenia wyroku, przed jego ujawnieniem, prezydent Rosji wysłał pojednawczy sygnał, świadczący o gotowości do dyskusji z Ukrainą na temat warunków utrzymania dostaw przez jej terytorium na warunkach korzystnych ekonomicznie. Kiedy jednak okazało się, że Gazprom przegrał w sądzie spór o umowę przesyłową, brak podpisu pod wspomnianym aneksem posłużył za pretekst, by nie uruchamiać dostaw gazu od 1 marca i to mimo odbioru przedpłat przez rosyjską firmę. $\mathrm{Z}$ dokumentów ukraińskiego rządu, które znajdują się w posiadaniu autora, wynika, że Gazprom przy wielu świadkach miał przekonywać w toku negocjacji trwających w okresie styczeń-luty 2018 r., że dodatek do wyroku ma być jedynie udogodnieniem ${ }^{18}$. Szkic domniemanego aneksu został stworzony przez Naftogaz i wysłany do Gazpromu w lutym tego roku.

W tygodniu poprzedzającym wyrok w sprawie umowy tranzytowej rosyjski koncern odrzucił szkic, argumentując, że nie jest on potrzebny do rewizji kontraktu. $Z$ tego powodu Naftogaz przekazał przedpłatę w wysokości $127 \mathrm{mln}$ USD za dostawy $0,5 \mathrm{mld}^{3} \mathrm{w}$ marcu, czyli około $18 \mathrm{mln}^{3}$ dziennie od 1 marca. Gazprom potwierdził otrzymanie przedpłat. Mimo to 28 lutego rosyjska spółka opóźniła przekazanie standardowych nominacji o udostępnienie przepustowości przez Ukrtransgaz, operatora gazociągów przesyłowych należącego do Naftogazu. To podstawowy dokument uzasadniający codzienną współpracę. W tym czasie pracownicy Gazpromu mieli przestać reagować na telefony i wiadomości. Nominacje przekazane ostatecznie Ukrtransgazowi nie zawierały wolumenu zamówionego przez Naftogaz (mogły zawierać zamówienia innych użytkowników sieci rosyjskiej).

Odmawiając świadczenia dostaw w marcu, Gazprom uniemożliwił Naftogazowi realizację wyroku arbitrażu poprzez zakup minimalnej ilości gazu z Rosji (4 $\mathrm{mld}^{3}$ rocznie). Naftogaz podał, że nigdy w historii importu z Europy nie spotkał się z takim traktowaniem przez firmę. Spółka utrzymuje, że w przeszłości nigdy nie było tak, żeby przekazała przedpłatę i nie

17 Stanowisko non-paper rządu ukraińskiego, On the situation with gas supplies and transit, 2.03.2018, w posiadaniu autora.

18 Jakóbik: Ukraina ujawnia. Gazprom celowo wywołat kryzys dostaw, BiznesAlert.pl, 6.03. 2018, https://biznesalert.pl/gazprom-naftogaz-arbitraz-kryzys-celowo (dostęp: 8.03.2018). 
dostała gazu ${ }^{19} .2$ marca Gazprom oficjalnie poinformował, że zamierza się wycofać z kontraktu na dostawy z Naftogazem. Dzienne zapotrzebowanie na gaz na Ukrainie to obecnie ponad $100 \mathrm{mln} \mathrm{m}^{3}$. Większość $\mathrm{z}$ tego pokrywa się z zapasów przechowywanych w magazynach gazu. Jest one wykorzystywane z pełną przepustowością. Jedną trzecią dziennego zapotrzebowania pokrywa się z wydobycia krajowego, a resztę przez import gazu z Unii Europejskiej. $Z$ tego względu 1 marca Naftogaz musiał szybko podpisać kontrakt na dodatkowe $18 \mathrm{mln} \mathrm{m}^{3}$ dziennie, by uzupełnić niedobór spowodowany działaniem Gazpromu. W związku z tym Ukraina wprowadziła nadzwyczajne środki mające na celu zapewnienie bezpieczeństwa dostaw: obniżenie temperatur w sektorze publicznym i przemysłowym, przestawienie się na inne paliwa, czasowe zamknięcie instytucji publicznych, jak szkoły oraz przedszkola. Na wezwanie władz odpowiedziało społeczeństwo, które obniżyło temperatury $\mathrm{w}$ domach o 1-2 stopnie $\mathrm{w}$ następnych trzech dniach po rozpoczęciu kryzysu. W wyniku nadzwyczajnej sytuacji Naftogaz podpisał z Polskim Górnictwem Naftowym i Gazownictwem (PGNiG) kontrakt dotyczący interwencyjnych dostawach gazu. Obowiązuje on do końca marca 2018 r. i opiewa na $60 \mathrm{mln} \mathrm{m}^{3}$. Dostawy ruszyły 2 marca o godzinie 6.00 czasu ukraińskiego przez połączenie w Hermanowicach. Pozwolą one znieść nadzwyczajne środki bezpieczeństwa $\mathrm{w}$ najbliższej przyszłości ${ }^{20}$. Ukraina 1 marca poinformowała Komisję Europejską o problemie. Poprosiła ją o zorganizowanie jak najszybciej trójstronnych negocjacji w formacie KE-Ukraina-Rosja, uruchomienie mechanizmu wczesnego ostrzegania w zgodzie $\mathrm{z}$ art. 340 umowy Stowarzyszeniowej UE-Ukraina.

\section{Konsekwencje dla Ukrainy}

Istnieje prawdopodobieństwo, że Gazprom skorygował swą politykę w interesie Rosji, która być może chciała wykorzystać destabilizację portfela dostaw Naftogazu w celu uzyskania destabilizacji politycznej na Ukrainie. Odbyłoby się to jednak wbrew interesom rosyjskiego koncernu, ponieważ wiązałoby

19 Gazprom refusalto supply gas violates Stockholm Tribunal ruling, Naftogaz, 1.03.2018, www. naftogaz.com/www/3/nakweben.nsf/0/72AFCEDE314F365EC225824300465063?OpenDocument\&Highlight=0,gazprom\%20supplies (dostęp: 22.05.2018).

20 Naftogaz urgently buys gas from PGNiG after Gazprom's withdrawal from starting deliveries to Ukraine, PGNiG, 2.03.2018, http://en.pgnig.pl/news/-/news-list/id/naftogazurgently-buys-gas-from-pgnig-after-gazprom-s-withdrawal-from-starting-deliveries-toukraine/newsGroupId/1910852 (dostęp: 22.05.2018). 
się z uszczerbkiem na jego wizerunku. Autor zakłada, że celem politycznym Federacji Rosyjskiej była dezorganizacja sektora gazowego na Ukrainie. W ten sposób można było osiągnąć destabilizację polityczną w razie kryzysu dostaw gazu, destabilizację ekonomiczną, w razie problemów finansowych w wyniku destabilizacji Naftogazu, a także utrudnić reformy sektora gazowego w zgodzie Z wymogami trzeciego pakietu energetycznego. Z punktu widzenia rosyjskiego koncernu gazowego polityka ta była sprzeczna z celem ekonomicznym, jakim powinna być maksymalizacja zysków ze sprzedaży gazu. Wyrok arbitrażu dawał Gazpromowi gwarancję sprzedaży co najmniej $4 \mathrm{mld} \mathrm{m}^{3}$ gazu ziemnego rocznie Naftogazowi, bo narzucał taki obowiązek na tę firmę. Podważanie prawomocnego wyroku obniżyło wiarygodność tego sprzedawcy w oczach obecnych i potencjalnych klientów. Rosyjska firma toczy spory arbitrażowe z innymi koncernami europejskimi, np. z polskim PGNiG, które po kryzysie gazowym z marca 2018 r. na Ukrainie nie może być pewne, czy nawet po zwycięstwie sądowym uzyska oczekiwane ustępstwa od strony rosyjskiej. Działania Gazpromu skrytykowała Komisja Europejska ${ }^{21}$, USA ${ }^{22}$, a nawet $\mathrm{Niemcy}^{23}$, na których terytorium ma wyjść na brzeg gazociąg Nord Stream $2^{24}$. Pierwotnie Gazprom mógł chcieć wykorzystać spór z Naftogazem jako uzasadnienie realizacji tego projektu. Jednak jest to argument za polityczną decyzją o zablokowaniu projektu. Rosjanom może chodzić o zatrzymanie integracji europejskiej Ukrainy przez destabilizowanie jej sektora gazowego. Według Komisji Europejskiej stabilność dostaw gazu przez terytorium ukraińskie warunkuje stabilność ekonomiczną ${ }^{25}$. Był to jeden $\mathrm{z}$ argumentów Trybunału Arbitrażowego za wydaniem wyroku niekorzystnego dla strony rosyjskiej. Gazprom krytykował tę argumentację w mediach. W przekonaniu przedstawicieli koncernu oznaczało to, że skoro według Komisji Europejskiej powinien utrzymać dostawy przez terytorium ukraińskie, bo w innym wypadku

21 European Commission, Statement of Vice-President Sefcovic on natural gas situation following contacts with Russian-Ukrainian counterparts, 4.03.0218, http://europa.eu/rapid/ press-release_STATEMENT-18-1561_en.htm (dostęp: 22.05.2018).

22 State Dept calls on Gazprom to resume gas supplies through Ukraine, Interfax-Ukraine, 3.03.2018, https://en.interfax.com.ua/news/general/489338.html (dostęp: 22.05.2018).

23 Germany calls on Gazprom, Ukraine's Naftogaz to settle dispute, Reuters, 5.03.2018, www.reuters.com/article/russia-ukraine-germany/germany-calls-on-gazprom-ukrainesnaftogaz-to-settle-dispute-idUSS8N1QC01L (dostęp: 22.05.2018).

24 To projekt magistrali z Rosji do Niemiec przez Morze Bałtyckie o przepustowości $55 \mathrm{mld} \mathrm{m}^{3}$, a zatem analogicznej do pierwszego Nord Stream, który od 2012 r. transportuje gaz przez Bałtyk. Zob.: W. Jakóbik, Polska miażḋy Nord Stream 2. Ujawniamy opinię prawników, BiznesAlert.pl, 16.10.2017, https://biznesalert.pl/nord-stream-2-analiza-prawna-polska-2 (dostęp: 24.03.2018).

25 European Commission, Statement of Vice-President Sefcovic... 
Kijowowi grozi destabilizacja ekonomiczna, to oznacza, że rosyjska firma faktycznie ma finansować stabilizację na Ukrainie ${ }^{26}$, co jest dla Gazpromu niekorzystne ekonomicznie ${ }^{27}$. Ten argument można odeprzeć. W pierwszym okresie relacji gazowych Rosja-Ukraina, poprzedzającym kryzysy gazowe, Gazprom oferował stronie ukraińskiej subsydiowane ceny gazu, a tym samym finansował jej stabilność ekonomiczną, co odbywało się prawdopodobnie w celu realizacji polityki Kremla. Utrzymanie stabilnych dostaw przez ten kraj jest warunkiem realizacji projektu stawianym przez rząd niemiecki ${ }^{28}$. Niezależnie od tego jak zdefiniuje takie dostawy Berlin bądź Bruksela, destabilizacja z początku marca $2018 \mathrm{r}$., polegająca na zaskoczeniu partnera ukraińskiego rezygnacją z realizacji prawomocnego wyroku arbitrażu, zadziała prawdopodobnie na niekorzyść wizerunku Gazpromu jako pewnego dostawcy i Nord Stream 2 jako projektu zwiększającego bezpieczeństwo dostaw. Należy wziąć pod uwagę możliwość, że działania Gazpromu były mniej agresywne niż w poprzednich latach z powodu zaangażowania Unii Europejskiej w reformy sektora gazowego Ukrainy. Warto przy tym zaznaczyć, że Polska ostrzega, iż zgoda na sporny gazociąg ułatwi Moskwie destabilizację sytuacji na Ukrainie, a nawet uczyni bardziej uprawdopodobną eskalację działań zbrojnych ${ }^{29}$. Przed nowym kryzysem w marcu Ukraina sygnalizowała gotowość do przywrócenia importu z Rosji po atrakcyjnej cenie. Po odmowie Gazpromu uruchomienia dostaw maleją szanse na kolejne dostawy od tej firmy dla Naftogazu ${ }^{30}$. Obawy państw Unii Europejskiej związane z Nord Stream 2 mogą wpłynąć na przyspieszenie prac Komisji Europejskiej nad rewizją dyrektywy gazowej, która może podporządkować sporny projekt prawu unijnemu, a co za tym idzie, opóźnić jego realizację przez konieczność rewizji założeń31.

26 Germany urges Moscow and Kiev to ensure stable Energy flows, The Irish Times, 6.03.2018, www.irishtimes.com/business/energy-and-resources/germany-urges-moscow-and-kiev-toensure-stable-energy-flows-1.3416602 (dostęp: 23.05.2018).

27 Russia's Gazprom says has started terminating gas contracts with Ukraine, Business Insider, 3.03.2018, www.businessinsider.com/r-russias-gazprom-says-has-started-terminatinggas-contracts-with-ukraine-2018-3?IR=T (dostęp: 24.03.2018).

28 Preserving gas transit through Ukraine is condition for implementing Nord Stream 2 project, Interfax, 17.02.2018, http://en.interfax.com.ua/news/economic/485833.html (dostęp: 18.03.2018).

29 Mateusz Morawiecki: Nord Stream 2 przybliza nas do wojny, Wirtualny Nowy Przemysł, 15.02.2018, http://gazownictwo.wnp.pl/mateusz-morawiecki-nord-stream-2-przyblizanas-do-wojny,317510_1_0_0.html (dostęp: 18.03.2018).

30 Ukraina sprowadzi więcej gazu z Zachodu, ale liczy na rabat w Rosji. , Wszystko zależy od arbitrażu”, BiznesAlert.pl, 4.03.2018, http://biznesalert.pl/ukraina-rosja-gaz-arbitraz (dostęp: 24.03.2018).

31 Buzek: Rewizja dyrektywy gazowej ochroni rynek UE, choć może zniechęcić do Nord Stream 2 (rozmowa), BiznesAlert.pl, 5.02.2018, http://biznesalert.pl/lex-nord-stream-2dyrektywa-gazowa-ochrona-rynku-ue (dostęp: 18.03.2018). 
Brak dostaw w marcu zmusił Ukrainę do wprowadzenia rozwiązań chroniących przed zatrzymaniem dostaw transportowanych przez jej terytorium. Bez odpowiedniego ciśnienia w gazociągach byłyby zagrożone również dostawy do klientów europejskich. Odezwa rządu ukraińskiego o ograniczenie poboru gazu spotkała się z reakcją społeczeństwa ukraińskiego, zamknięto szkoły i przedszkola, oszczędzano zużycie gazu w gospodarstwach domowych. Po sporze arbitrażowym z marca 2018 r. następuje nowy etap relacji gazowych Ukraina-Rosja, który OSW nazywa emancypacją. Działania Rosji z wykorzystaniem Gazpromu doprowadziły do inicjacji dążeń mających na celu uniezależnienie się od niego Ukrainy na stałe. Komisja Europejska chce negocjować z obydwoma państwami warunki utrzymania minimalnego poziomu dostaw przez terytorium Ukrainy, mimo oskarżeń Rosjan, że chodzi o przymusowe subsydiowanie gospodarki ukraińskiej zależnej od tranzytu na koszt Gazpromu. Europejskie spółki interesują się inwestycją w ukraińskie gazociągi i magazyny. Podsumowując, kryzys gazowy w relacjach Federacji Rosyjskiej z Ukrainą przyczynia się do integracji energetycznej państwa Petra Poroszenki z Unią Europejską, a ta z kolei może doprowadzić do osłabienia wpływu Gazpromu na politykę Ukrainy.

\section{Konsekwencje dla polityki zagranicznej Federacji Rosyjskiej}

Z analizy wynika, że Gazprom jest wykorzystywany do realizacji celów politycznych Rosji, co może odbywać się kosztem interesów ekonomicznych tej firmy. W przekonaniu Komisji Europejskiej projekt Nord Stream 2 ma charakter polityczny i nie jest zgodny z polityką energetyczną UE ${ }^{32}$. Komisja przewiduje również niższy wzrost zapotrzebowania na gaz ziemny w Unii Europejskiej, niż spodziewają się tego naukowcy Rosyjskiej Akademii Nauk ${ }^{33}$. Tymczasem ich prognozy są przedstawiane jako jeden $z$ argumentów za budową nowego gazociągu z Rosji do Niemiec. Jeżeli są one zawyżone, to oznaczałoby, że rosyjski koncern inwestuje w przedsięwzięcie trudne do uzasadnienia z punktu widzenia ekonomicznego. Jednak, zgodnie z ustaleniami badaczy zawartymi w przywołanej literaturze, interesy ekonomiczne Gazpromu schodzą na drugi plan wobec prowadzonej polityki, zgodnie z którą Rosja chce

32 Wiceszef Komisji Europejskiej, Nord Stream 2 to projekt polityczny, Niezależna.pl, 13.03.2018, http://niezalezna.pl/219538-wiceszef-komisji-europejskiej-nord-stream-2to-projekt-polityczny (dostęp: 17.04.2018).

33 P. Turowski, Eksport rosyjskiego gazu - strategia, plany, konsekwencje, „Bezpieczeństwo Narodowe" 2012, nr II-IV (23-24), s. 225. 
utrzymać wpływ na sytuację wewnętrzną Ukrainy i ją destabilizować, także przy użyciu przerw lub ograniczeń dostaw gazu ziemnego. Jeżeli potwierdzą się informacje przekazane przez ukraiński Naftogaz na temat wykorzystania dodatkowego z nim porozumienia, które zostało użyte przez Gazprom, jako pretekstu do niedostarczenia gazu nad Dniepr, byłby to dowód potwierdzający powyższą tezę. Przemawiałby za kontynuacją polityki dywersyfikacji w krajach Unii Europejskiej i przeciwko zaangażowaniu europejskich firm w sporny projekt Nord Stream 2 . W praktyce widać jednak utrzymujące się zaangażowanie partnerów finansowych z Unii Europejskiej w to przedsięwzięcie, które pozwoliłoby Rosji na większe możliwości wykorzystywania Gazpromu do realizacji celów polityki zagranicznej Kremla. Może to świadczyć o tym, że ich priorytetem jest pozyskanie taniego gazu rosyjskiego ${ }^{34}$. Problem polega na tym, że takiej alternatywy może już nie mieć Ukraina, pozbawiona tranzytu gazu z Rosji. Z badań Komisji Europejskiej wynika, że Nord Stream 2 może sprawić, iż w okresie zwiększonego importu gazu do Europy Północno-Zachodniej dojdzie do istotnej podwyżki jego cen w Europie Środkowo-Wschodniej, w tym na Ukrainie. Projekt może zatem posłużyć do dalszej polityki cenowej znanej z historii rosyjskiej firmy ${ }^{35}$. $\mathrm{Z}$ tego względu kluczowe wydają się rozmowy na temat utrzymania minimalnego poziomu dostaw z użyciem tego szlaku proponowane przez Komisję Europejską ${ }^{36}$. W kwietniu 2018 r. doszło do ważnej deklaracji Niemiec, których spółki są zaangażowane w Nord Stream 2. Kanclerz Angela Merkel przyznała, że projekt ma „wymiar polityczny”. Opowiedziała się za utrzymaniem poziomu dostaw przez Ukrainę, który zagwarantuje stabilnośćc ${ }^{37}$. Chociaż Niemcy nadal uważają, że Nord Stream 2 jest uzasadniony z punktu widzenia biznesowego, prawdopodobnie ze względu na narastającą krytykę projektu w państwach członkowskich UE i sceptycyzm Komisji Europejskiej popierają rozmowy o utrzymaniu dostaw przez Ukrainę. Po raz kolejny w historii zaangażowanie UE na Ukrainie może uchronić państwo to przez działaniami

34 J. Gratz, Russia's Pipeline Overtstretch: Market Monopolisation at the Expense of Reliability, „Russian Analytical Digest” 2013, nr 113, s. 9-12.

35 REKK,Ernst\&Young, Quovadis gasmarketregulatoryframework, luty2018, s. 7-9, https:// rekk.hu/analysis-details/249/quo_vadis_eu_gas_market_regulatory_framework_study_ on_a_gas_market_design_for_europe (dostęp: 23.05 .2018$)$.

36 Komisja Europejsk̄a chce rozmów o przyszłości dostaw gazu z Rosji przez Ukrainę, BiznesAlert.pl, 22.02.2018, https://biznesalert.pl/rosja-ukraina-gaz-tranzyt-przesyl-komisja-europejska-rozmowy (dostęp: 18.03.2018),

37 Merkel przyznaje: Nord Stream 2 to też polityka, BiznesAlert.pl, 10.04.2018, https://biznesalert.pl/nord-stream-2-rosja-niemcy (dostęp: 17.04.2018). 
destabilizującymi Gazpromu, podejmowanymi na zlecenie Kremla. Nawet jeżeli wsparcie Komisji Europejskiej będzie mogło zapewnić jedynie to minimum, to dla Kijowa jest ono kwestią kluczową.

Potencjalne skutki kolejnego elementu długofalowych działań Gazpromu, czyli kryzysu gazowego na Ukrainie z marca 2018 r., można przeanalizować w ramach trzech scenariuszy. Unia Europejska mogłaby zaostrzyć politykę wobec Gazpromu, np. przez nałożenie na Nord Stream 2 regulacji antymonopolowych, co może wpłynąć na zmniejszenie się poparcia dla niego ze strony Republiki Federalnej Niemiec (RFN). Taka zmiana oznaczałaby osłabienie wpływów Gazpromu, a zatem i polityki zagranicznej Kremla na Europę Środkowo-Wschodnią przez blokadę przedsięwzięcia, które mogłoby ugruntować jego pozycję na tych rynkach, a z nią - wpływ polityczny Kremla. Unia Europejska mogłaby także za pośrednictwem Komisji Europejskiej doprowadzić do kompromisu zakładającego utrzymanie minimalnych dostaw gazu przez Ukrainę i jednoczesną budowę gazociągu Nord Stream 2. Oznaczałoby to utrzymanie status quo. Nie przekreśliłoby to dalszej integracji gazowej Ukrainy za pośrednictwem Wspólnoty Energetycznej, której zagroziłaby destabilizacja wywołana zatrzymaniem tranzytu rosyjskiego gazu przez terytorium tego kraju.

Doszło do realizacji najbardziej prawdopodobnego scenariusza, znów, z powodu poparcia RFN takiego rozwiązania ${ }^{38}$. Znaczenie Niemiec dla rozstrzygnięcia $w$ tej sprawie wynika $z$ faktu, że to na ich terytorium ma wychodzić na brzeg gazociąg Nord Stream 2, a bez zgody Berlina prawdopodobnie nie będzie możliwe jego zablokowanie. Inny scenariusz to brak działania Unii Europejskiej i pozostawienie rozstrzygnięcia sporu bilateralnym relacjom Rosja-Ukraina. Ograniczeniem dla jego realizacji byłoby stowarzyszenie Ukrainy ze Wspólnotą Energetyczną, która z jednej strony narzuca na nią obowiązek implementacji prawa unijnego, ale z drugiej zobowiązuje Komisję Europejską do zaangażowania w roli arbitra sporów ukraińsko-rosyjskich. To dowód na to, że integracja energetyczna z Unią Europejską już teraz stanowi dla Ukrainy formę tarczy ochronnej przed nadużyciami Gazpromu. Dzięki niej scenariusz, który byłby najmniej pożądany z punktu widzenia Ukrainy, nie był możliwy do zrealizowania ${ }^{39}$.

38 Niemcy umywaja ręce $w$ sporze gazowym Rosja-Ukraina, BiznesAlert.pl, 6.03.2018, http://biznesalert.pl/niemcy-rosja-ukraina-arbitraz-nord-stream-2 (dostęp: 24.03.2018).

39 Komisja Europejska chce rozmów o przyszłości dostaw gazu z Rosji przez Ukrainę, BiznesAlert.pl, 22.02.2018, http://biznesalert.pl/rosja-ukraina-gaz-tranzyt-przesyl-komisjaeuropejska-rozmowy (dostęp: 24.03.2018). 


\section{Wnioski dla koncepcji prometeizmu energetycznego}

Z przeprowadzonego wywodu wynika, że skutkiem rosyjsko-ukraińskiego kryzysu gazowego mogą być sprzyjające warunki do rozwoju koncepcji prometeizmu energetycznego, czyli zwalczania imperializmu rosyjskiego w sektorze energetycznym przez przekazywanie na Wschód wolności, którą w sektorze dają regulacje antymonopolowe trzeciego pakietu energetycznego Unii Europejskiej.

Ukraina zwróciła się do Komisji Europejskiej z prośbą o zaangażowanie w rozmowy z Federacją Rosyjską, a Komisja zadeklarowała udział w negocjacjach trójstronnych. Ciekawym tematem dalszej analizy byłaby rola Niemiec, które zaoferowały swój udział w rozmowach ${ }^{40}$.

To, że Gazprom pozostaje narzędziem polityki zagranicznej Federacji Rosyjskiej, oznacza, iż służy realizacji jej aspiracji imperialnych. W okresie po rozpadzie Związku Sowieckiego może zastępować „tradycyjne” narzędzia, co przebija się ze strategii energetycznej Federacji do 2020 r. ${ }^{41}$ Jeżeli Gazprom jest narzędziem realizacji polityki Rosji, to aktualna pozostaje koncepcja prometeizmu energetycznego, czyli zwalczania imperializmu rosyjskiego przez przekazywanie na Wschód wolności, którą w sektorze energetycznym dają regulacje trzeciego pakietu energetycznego. Warto przy tym zauważyć, że wyrok Trybunału Arbitrażowego na korzyść Naftogazu otwiera drogę do restrukturyzacji tej firmy w celu przygotowania jej do zasadniczej zmiany w związku z pakietem energetycznym, czyli rozdziału właścicielskiego i powołania niezależnego operatora gazociągów przesyłowych, w którym udziały potencjalnie mogłaby przejąć firma z Unii Europejskiej. To szansa na ustabilizowanie przesyłu gazu przez Ukrainę, a co za tym idzie sytuacji politycznej w tym kraju. W przyszłości może także przysłużyć się zmniejszeniu zależności budżetu ukraińskiego od przychodów z tranzytu gazu. W celu ograniczenia wpływu polityki zagranicznej Kremla za pośrednictwem Gazpromu niezbędne jest dalsze wykorzystanie zagranicznego wymiaru polityki energetyczno-klimatycznej Unii Europejskiej do wprowadzania regulacji antymonopolowych, dywersyfikacji szlaków, źródeł dostaw gazu ziemnego, rewizji kontraktów na dostawy oraz przesył gazu ziemnego, które są niezgodne z prawem unijnym. W przy-

40 Merkel: No Nord Stream 2 without guarantee for Ukraine's gas transit role, EurActiv. com, 10.04.2018, www.ogj.com/articles/print/volume-104/issue-11/transportation/russianukraine-dispute-highlights-need-for-supply-diversification.html (dostęp: 23.05.2018).

41 E. Wyciszkiewicz, Wprowadzenie, w: E. Wyciszkiewicz (red.), Geopolityka rurociagów, s. 7. 
padku Ukrainy oznacza to konieczność dalszej reformy sektora gazowego w zgodzie z oczekiwaniami Wspólnoty Energetycznej, a także niezmienną od lat potrzebę dalszego rozwoju współpracy gazowej z alternatywnymi dostawcami $^{42}$. Oznacza również, że przy wsparciu Komisji Europejskiej i przy wykorzystaniu korzystnych wyroków Trybunału Arbitrażowego państwo ukraińskie może doprowadzić do rewizji kontraktów z Gazpromem.

Dla polskiej polityki zagranicznej istotne będzie, że takie działania doprowadzą do ustabilizowania sytuacji gospodarczej oraz politycznej w kraju, który oddziela Polskę na dużym odcinku granicy wschodniej od Federacji Rosyjskiej. To także perspektywa rozwoju handlu gazem i wykorzystania ukraińskiej infrastruktury przesyłowej oraz magazynowej. To wreszcie realizacja koncepcji autora tekstu, czyli prometeizmu energetycznego, zgodnie z którą zmniejszony zostanie wpływ rosyjskiej polityki zagranicznej realizowanej za pośrednictwem Gazpromu na Ukrainie jak najdalej od granic Rzeczpospolitej Polskiej, z użyciem narzędzi dostępnych w Unii Europejskiej. Być może za wcześnie jest na propozycję całościowej myśli prometeizmu energetycznego, ale na pewno stanowi to dobry przyczynek do dyskusji na ten temat.

\section{Bibliografia}

Bączkowski W., Czy prometeizm jest fikcja i fantazją?, w: W. Bączkowski, O wschodnich problemach Polski, oprac. J. Kloczkowski, P. Kowal, Ośrodek Myśli Politycznej, Księgarnia Akademicka, Kraków 2000.

Bieliszczuk B., Komentarz PISM: Rozstrzygnięcie w sprawie Naftogaz-Gazprom: porażka Rosji, szansa dla Ukrainy, 1.03.2018, www.pism.pl/publikacje/komentarz/nr-11-2018.

Bieliszczuk B., Gawlikowska-Fyk A., Komentarz PISM: Konflikt gazowy Rosja-Ukraina-kolejna odstona, 5.03.2018, www.pism.pl/publikacje/komentarz/nr-13-2018.

Bieliszczuk B., Gawlikowska-Fyk A., Komentarz PISM: Werdykt Trybunału Arbitrażowego w sporze Gazprom-Naftogaz, 11.06.2017, www.pism.pl/publikacje/komentarz/nr-18-2017.

Buzek: Rewizja dyrektywy gazowej ochroni rynek UE, choć może zniechęcić do Nord Stream 2 (rozmowa), BiznesAlert.pl, 5.02.2018, http://biznesalert.pl/lex-nord-stream-2-dyrektywa-gazowa-ochrona-rynku-ue.

Gazprom refusal to supply gas violates Stockholm Tribunal ruling, Naftogaz, 1.03.2018, www.naftogaz.com/www/3/nakweben.nsf/0/72AFCEDE314F365EC225824300465063? OpenDocument\&Highlight $=0$,gazprom $\% 20$ supplies.

Germany calls on Gazprom, Ukraine's Naftogaz to settle dispute, Reuters, 5.03.2018, www. reuters.com/article/russia-ukraine-germany/germany-calls-on-gazprom-ukraines-naftogaz-to-settle-dispute-idUSS8N1QC01L.

42 Russian-Ukrainedisputehighlitsneedforsupplydiversification,Oil\&GasJournal,20.03.2006, www.ogj.com/articles/print/volume-104/issue-11/transportation/russian-ukraine-dispute-highlights-need-for-supply-diversification.html (dostęp: 23.05.2018). 
Germany Urges Moscow and Kiev to Ensure Stable Energy Flows, The Irish Times, 6.03.2018, www.irishtimes.com/business/energy-and-resources/germany-urges-moscow-and-kiev-to-ensure-stable-energy-flows-1.3416602.

Gratz J., Russia's Pipeline Overtstretch: Market Monopolisation at the Expense of Reliability, „Russian Analytical Digest” 2013, nr 113.

Jakóbik: Ukraina ujawnia. Gazprom celowo wywołat kryzys dostaw, BiznesAlert.pl, 6.03.2018, https://biznesalert.pl/gazprom-naftogaz-arbitraz-kryzys-celowo.

Jakóbik W., Polska miażdży Nord Stream 2. Ujawniamy opinię prawników, BiznesAlert.pl, 16.10.2017, https://biznesalert.pl/nord-stream-2-analiza-prawna-polska-2.

Jakóbik W., Prometeizm energetyczny. Między kawiarniq a politechnika, „Pressje” 2013, teka 32/33.

Kardaś S., Iwański T., Od wasalizacji do emancypacji. Rewizja modelu ukraińsko-rosyjskiej wspótpracy gazowej, Ośrodek Studiów Wschodnich, 7.03.2018, www.osw.waw.pl/pl/publikacje/ komentarze-osw/2018-03-07/od-wasalizacji-do-emancypacji-rewizja-modelu-ukrainsko.

Kardaś S., Konończuk W., Łoskot-Strachota A., Negocjacje gazowe Ukraina-Rosja-UE: wojna pozycyjna, Ośrodek Studiów Wschodnich, 8.10.2017, www.osw.waw.pl/pl/publikacje/ analizy/2014-10-08/negocjacje-gazowe-ukraina-rosja-ue-wojna-pozycyjna.

Komisja Europejska chce rozmów o przyszłości dostaw gazu z Rosji przez Ukrainę, BiznesAlert.pl, 22.02.2018, https://biznesalert.pl/rosja-ukraina-gaz-tranzyt-przesyl-komisja-europejska-rozmowy.

Kowal P., Jakóbik W., Polityka energetyczna UE wobec państw Partnerstwa Wschodniego (2008-2014), w: M. Grela, Z. Rapacki (red.), Partnerstwo Wschodnie Unii Europejskiej, Akademia Finansów i Biznesu Vistula, Warszawa 2016.

Libera P., II Rzeczpospolita wobec ruchu prometejskiego, Centralne Archiwum Wojskowe im. mjr. Bolesława Waligóry, Warszawa-Tetragon 2013.

Mateusz Morawiecki: Nord Stream 2 przybliza nas do wojny, Wirtualny Nowy Przemysł, 15.02.2018, http://gazownictwo.wnp.p1/mateusz-morawiecki-nord-stream-2-przybliza-nas-do-wojny,317510_1_0_0.html.

Merkel:NoNordStream2 withoutguaranteeforUkraine's gastransitrole, EurActiv.com, 10.04.2018, www.ogj.com/articles/print/volume-104/issue-11/transportation/russian-ukraine-dispute-highlights-need-for-supply-diversification.html.

Merkel przyznaje: Nord Stream 2 to też polityka, BiznesAlert.pl, 10.04.2018, https://biznesalert.pl/ nord-stream-2-rosja-niemcy.

Michalczyk L., Polska a Gazprom w dlugofalowej koncepcji polskiego bezpieczeństwa energetycznego, „Polityka Energetyczna” 2011, t. 14, z. 1.

Naftogaz urgently buys gas from PGNiG after Gazprom's withdrawal from starting deliveries to Ukraine, PGNiG, 2.03.2018, http://en.pgnig.pl/news/-/news-list/id/naftogaz-urgentlybuys-gas-from-pgnig-after-gazprom-s-withdrawal-from-starting-deliveries-to-ukraine/ newsGroupId/1910852.

Naftogaz wins the gas sales arbitration case against Gazprom on all issues in dispute, Naftogaz, 22.12.2017, www.naftogaz.com/www/3/nakweben.nsf/0/1CBBBA42E2336FDCC22581 FE0042E27F?OpenDocument\&year=2017\&month=12\&nt=News\&.

Niemcy umywaja ręce w sporze gazowym Rosja-Ukraina, BiznesAlert.pl, 6.03.2018, http:// biznesalert.pl/niemcy-rosja-ukraina-arbitraz-nord-stream-2.

Nord Stream 2 to projekt polityczny, wypowiedź wiceszefa Komisji Europejskiej, Niezależna. pl, 13.03.2018, http://niezalezna.pl/219538-wiceszef-komisji-europejskiej-nord-stream-2-to-projekt-polityczny. 
Preserving gas transit through Ukraine is condition for implementing Nord Stream 2 project, Interfax, 17.02.2018, http://en.interfax.com.ua/news/economic/485833.html.

Pronińska K.M., Bezpieczeństwo energetyczne w stosunkach UE-Rosja, Dom Wydawniczy Elipsa, Warszawa 2012.

REKK, Ernst\&Young, Quo vadis gas market regulatory framework, luty 2018, https://rekk.hu/ analysis-details/249/quo_vadis_eu_gas_market_regulatory_framework_study_on_a_ gas_market_design_for_europe.

Russia's Gazprom says has started terminating gas contracts with Ukraine, Business Insider, 3.03.2018, www.businessinsider.com/r-russias-gazprom-says-has-started-terminating-gascontracts-with-ukraine-2018-3? IR=T.

Russian-Ukraine dispute highlits need for supply diversification, Oil\&Gas Journal, 20.03.2006, www.ogj.com/articles/print/volume-104/issue-11/transportation/russian-ukraine-disputehighlights-need-for-supply-diversification.html.

State Dept calls on Gazprom to resume gas supplies through Ukraine, Interfax-Ukraine, 3.03.2018, https://en.interfax.com.ua/news/general/489338.html.

Turowski P., Eksport rosyjskiego gazu - strategia, plany, konsekwencje, „Bezpieczeństwo Narodowe" 2012, nr II-IV (23-24).

Ukraina sprowadzi więcej gazu z Zachodu, ale liczy na rabat w Rosji. ,, Wszystko zależy od arbitrażu”, BiznesAlert.pl, 4.03.2018, http://biznesalert.pl/ukraina-rosja-gaz-arbitraz.

Ukraine had to buy gas in Europe at ransom price, EADaily, 5.03.2018, https://eadaily.com/ en/news/2018/03/05/ukraine-had-to-buy-gas-in-europe-at-ransom-price.

Win for Naftogaz in the Gas Transit Arbitration with Gazprom. Gazprom to pay USD 2.56 billion to Naftogaz, Naftogaz, 28.02.2018, www.naftogaz.com/www/3/nakweben.nsf/0/4927C1CECCAC4969C22582420076095F?OpenDocument\&year=2018\&month=02\&nt=News\&.

Wyciszkiewicz E. (red.), Geopolityka rurociagów. Wspótzależność energetyczna a stosunki międzypaństwowe na obszarze postsowieckim, Polski Instytut Spraw Międzynarodowych, Warszawa 2008.

Zawisza A., Gaz dla Polski. Zarys historii sektora gazu ziemnego w ostatnich dwóch dekadach w Polsce, Instytut Sobieskiego, Warszawa 2011.

Zygar M., Paniuszkin W., Gazprom. Rosyjska broń, przeł. K. Romanowska, W.A.B., Warszawa 2008. 